\title{
Microbial contributions to subterranean methane sinks
}

2 J. T. Lennon ${ }^{1} *$, D. Nguyễn-Thùy ${ }^{2}$, N. Phạm Đức ${ }^{3}$, A. Drobniak ${ }^{4}$, P. Tạ Hòa ${ }^{2}$, T.M. Pham ${ }^{3}$, T.

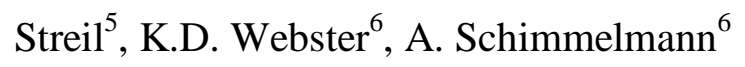

4

${ }^{1}$ Department of Biology, Indiana University, Bloomington, Indiana, USA

${ }^{2}$ Faculty of Geology, Vietnam National University, Hanoi, Vietnam

${ }^{3}$ Department of Microbiology, Vietnam National University, Hanoi, Vietnam

${ }^{4}$ Indiana Geological Survey, Indiana University, Bloomington, Indiana, USA

${ }^{5}$ SARAD GmbH, Dresden, Germany

$12 *$ corresponding author:

Jay T. Lennon

14 Department of Biology

1001 East 3rd Street

16 Indiana University

Bloomington, Indiana 47405

18 812-856-0962

lennonj@indiana.edu 


\begin{abstract}
24 Understanding the sources and sinks of methane $\left(\mathrm{CH}_{4}\right)$ is critical for predicting and managing global biogeochemical cycles. Recent studies have reported that $\mathrm{CH}_{4}$ concentrations in cave

26 ecosystems are depleted and that these subterranean environments may act as a daily sinks for atmospheric $\mathrm{CH}_{4}$. It has been hypothesized that this $\mathrm{CH}_{4}$ depletion may be caused by radiolysis,

28 an abiotic process whereby $\mathrm{CH}_{4}$ is oxidized via interactions with ionizing radiation derived from radon decay. Alternatively, the depletion of $\mathrm{CH}_{4}$ concentrations could be due to biological

30 processes, specifically oxidation by methanotrophic bacteria. We theoretically explored the radiolysis hypothesis and conclude that it is a kinetically constrained process that is unlikely to
\end{abstract}

32 lead to the rapid loss of $\mathrm{CH}_{4}$ in subterranean environments. We present experimental results to support this claim. We tested the microbial oxidation hypothesis in a set of mesocosm

34 experiments that were conducted in Vietnamese caves. Our results reveal that methanotrophic bacteria associated with cave rocks consume $\mathrm{CH}_{4}$ at a rate of $1.33-2.70 \mathrm{mg} \mathrm{CH} \cdot \mathrm{m}^{-2} \cdot \mathrm{d}^{-1}$. These

$36 \mathrm{CH}_{4}$ oxidation rates equal or exceed what has been reported in other habitats, including agricultural systems, grasslands, deciduous forests, and Arctic tundra. As such, microbial

38 methanotrophy has the potential to significantly oxidize $\mathrm{CH}_{4}$ in caves, but also smaller-size open subterranean spaces, such as cracks, fissures, and other pores that are connected to and rapidly

40 exchange with the atmosphere. Future studies are needed to understand how subterranean $\mathrm{CH}_{4}$ oxidation scales up to affect regional and global $\mathrm{CH}_{4}$ cycling. 


\section{INTRODUCTION}

Atmospheric methane $\left(\mathrm{CH}_{4}\right)$ is a potent greenhouse gas with rising concentrations that

48 can mainly be attributed to anthropogenic activities (IPCC, 2013; US EPA, 2015). Credible forecasting of global warming by climate models mandates knowledge about the sources and

50 sinks of atmospheric $\mathrm{CH}_{4}$. One potentially important, but overlooked sink of $\mathrm{CH}_{4}$ is the oxidation that occurs in subterranean environments. Recent studies have documented that cave ecosystems

52 sometimes have subatmospheric concentrations of $\mathrm{CH}_{4}$. For example, in a four-year study of St. Michael's Cave in Gibraltar, $\mathrm{CH}_{4}$ concentrations of cave air were typically 10 -fold below

54 atmospheric levels (Mattey et al., 2013). A similar pattern was documented in a set of Spanish caves with some samples having $\mathrm{CH}_{4}$ concentrations that were below detection limits suggesting 56 near-complete removal of $\mathrm{CH}_{4}$ from underground air (Fernandez-Cortes et al., 2015).

Two hypotheses have been put forth to explain the pattern of $\mathrm{CH}_{4}$ depletion in

58 subterranean environments. First, $\mathrm{CH}_{4}$ is a carbon and energy source that can be used by methanotrophic bacteria. Although methanotrophic bacteria were found in Movile Cave in

60 Romania (Hutchens et al., 2004), microbiological surveys of methane oxidizing bacteria in caves are relatively uncommon. Inferences about methanotrophy in caves have also been made based

62 on evidence from stable isotopes (Peryt et al., 2012). For example, an inverse relationship between $\mathrm{CH}_{4}$ concentrations and $\mathrm{CH}_{4}$ carbon stable isotope ratios (i.e., $\delta^{13} \mathrm{C}$ ) in St. Michael's

64 cave was considered a diagnostic signature of methanotrophy (Mattey et al., 2013). A second hypothesis is that $\mathrm{CH}_{4}$ depletion in subterranean ecosystems is due to radiolysis. This abiotic

66 mechanism of $\mathrm{CH}_{4}$ oxidation was developed to explain low $\mathrm{CH}_{4}$ concentrations in a poorly ventilated cave that had a high density of ions, but no recoverable methanotrophic bacteria

68 (Fernandez-Cortes et al., 2015). An inverse correlation between the concentration of $\mathrm{CH}_{4}$ and 
ions in cave air suggests that $\alpha$-particles from radon decay could contribute to removal of $\mathrm{CH}_{4}$

70 from subterranean environments (Fernandez-Cortes et al., 2015).

In this study, we evaluate the relative importance of biotic and abiotic mechanisms that

72 have been put forward to explain low concentrations of $\mathrm{CH}_{4}$ observed in subterranean environments. First, we develop theoretical expectations in an effort to constrain the rates of

74 radiolytic $\mathrm{CH}_{4}$ oxidation. Second, we present results from a controlled laboratory experiment aimed at quantifying the effect of ionizing radiation on the rate of $\mathrm{CH}_{4}$ oxidation. Third, we

76 discuss findings from a set of field mesocosm experiments in Vietnamese caves to quantify the methanotrophic potential of cave microbial communities.

\section{RESULTS AND DISCUSSION}

80 Weak theoretical support for the importance of radiolytic $\mathrm{CH}_{\mathbf{4}}$ oxidation - The following thought experiments reveal that radiolysis is a process that contributes minimally to $\mathrm{CH}_{4}$

82 oxidation in subterranean environments on the time scale of days to weeks. We arrive at this conclusion based on the imbalance between the large number of $\mathrm{CH}_{4}$ molecules and the

84 comparatively small number of radioactive decay events that are typical in caves.

Ionizing radiation in the air of subterranean limestone-based ecosystems is derived

86 predominantly from $\alpha$-particles that are generated during radon decay (Cigna, 2005; AlvarezGallego et al., 2005). These $\alpha$-particles could lead to the oxidation of $\mathrm{CH}_{4}$ via different

88 mechanisms. For example, radiolysis could result from the direct collision of $\alpha$-particles with $\mathrm{CH}_{4}$ molecules. In this case, an $\alpha$-particle splits a $\mathrm{CH}_{4}$ molecule, which triggers a subsequent

90 exothermic oxidation reaction of ions and radicals with atmospheric oxygen. However, with a decay rate of $\sim 35,000{ }^{222} \mathrm{Rn}$ atoms per second in a cubic meter of air, as measured in a Spanish 
92 cave (Fernandez-Cortes et al., 2015), it would take nearly 50 million years to eliminate 2 ppm of $\mathrm{CH}_{4}$ as a result of direct collision between $\alpha$-particles and $\mathrm{CH}_{4}$ molecules.

A more likely mechanism occurs when radiogenic energy interacts with water molecules and other major chemical constituents of cave air and thus produces ions and radicals that enter

96 secondary chemical reactions with $\mathrm{CH}_{4}$. For example, radiolysis of water vapor via radon decay could generate hydroxyl radicals $(\bullet \mathrm{OH})$ that act to remove $\mathrm{CH}_{4}$. However, if every $\alpha$-decay at

$9835,000 \mathrm{~Bq} \mathrm{~m}^{-3}$ generates $4.3 \cdot 10^{5}$ ions and radicals (Fernandez-Cortes et al., 2015), it would still require more than 100 years to eliminate $2 \mathrm{ppm}$ of $\mathrm{CH}_{4}$. In fact, this likely overestimates the

100 potential for radiolytic $\mathrm{CH}_{4}$ oxidation since the calculations unrealistically assume that all $\bullet \mathrm{OH}$ selectively react with $\mathrm{CH}_{4}$. In sum, our assumptions and calculations suggest that radiolysis is a

102 kinetically constrained process that is unlikely to act as a daily $\mathrm{CH}_{4}$ sink in subterranean ecosystems (Fernandez-Cortes et al., 2015). More detail on the calculations that were used to

104 arrive at our predictions can be found in the Supplementary Information,

106 Weak experimental support for the importance of radiolytic $\mathrm{CH}_{4}$ oxidation — Results from a laboratory experiment confirm our theoretical predictions by demonstrating that ionizing 108 radiation had a minimal effect on $\mathrm{CH}_{4}$ oxidation rates. We placed $7.08 \mathrm{~g}$ uranium metal powder in a Petri dish on the bottom of a humid polyethylene bag containing $43 \mathrm{~L}$ of air with an elevated

$110 \mathrm{CH}_{4}$ concentration $(23.5 \mathrm{ppm})$. The radioactivity inside the closed bag containing depleted uranium was approximately $2.5 \cdot 10^{6} \mathrm{~Bq} \mathrm{~m}^{-3}$, which is 70 -fold higher than the natural radiation

112 reported in Spanish cave air (Fernandez-Cortes et al., 2015). Yet, in the presence of strong ionizing radiation, $\mathrm{CH}_{4}$ was lost from the system at the slow rate of $0.197 \pm 0.0005( \pm$ standard

114 error) $\mathrm{ng} \mathrm{CH}_{4} \cdot \mathrm{m}^{-3} \cdot \mathrm{d}^{-1}$, which was indistinguishable from the diffusive loss of $\mathrm{CH}_{4}$ from 
polyethylene control bags lacking uranium (one-sample t-test: $\mathrm{t}_{6}=-0.97, P=0.37$, Fig. 1 ). More

116 detail concerning experimental procedures can be found in Supplementary Information.

118 Strong experimental support for the importance of biotic $\mathbf{C H}_{4}$ oxidation - The results from our field mesocosm experiments suggest that $\mathrm{CH}_{4}$ depletion can be achieved via the biological

120 activity of methanotrophic bacteria that are associated with rocks inside cave ecosystems. In two separate caves with low radon abundances $\left(\leq 100 \mathrm{~Bq} \mathrm{~m}^{-3}\right)$ on the island of Cát Bà in Vietnam, we

122 deployed 200-L polyethylene bags filled with cave air containing limestone rocks that were collected from inside the cave. Half of these mesocosms $(n=3)$ were treated with a $10 \%$ bleach

124 (sodium hypochlorite) solution to inhibit microbial activity ("dead") while the other mesocosms ("live") were treated with an equal volume of water $(\mathrm{n}=3)$. After incubating in situ overnight,

$126 \mathrm{CH}_{4}$ concentrations in the dead mesocosms were indistinguishable from the control mesocosms (no cave rocks) and the cave air (one-sample t-tests, $P>0.52$, Fig. 2). In contrast, we observed

128 an $87 \% \pm 0.047 \%$ (mean $\pm \mathrm{SEM}$ ) reduction of $\mathrm{CH}_{4}$ concentrations in the live mesocosms.

From our experimental data, we estimate that the rate of $\mathrm{CH}_{4}$ oxidation associated with

130 cave rocks was between 1.33 and $2.70 \mathrm{mg} \mathrm{CH} \cdot \mathrm{m}^{-2} \cdot \mathrm{d}^{-1}$. To the best of our knowledge, these are the first direct measurements of biological $\mathrm{CH}_{4}$ oxidation in a cave ecosystem. The magnitude of

132 these rates equals or exceeds the rates of $\mathrm{CH}_{4}$ oxidation that have been reported in soils from agricultural systems, grasslands, mature forests, and Arctic tundra (Whalen \& Reeburgh, 1990;

134 Suwanwaree \& Robertson, 2005; von Fischer et al., 2009). This comparison is noteworthy because caves maintain relatively constant temperatures thoughout the year, while soils in mid136 to-high latitudes often experience lower temperatures during the winter season, which results in reduces rates of $\mathrm{CH}_{4}$ oxidation (e.g., Groffman et al., 2006). As such, when integrated over 
138 annual time scales, subterranean enviornments like caves may act as a larger sink for atmospheric $\mathrm{CH}_{4}$ than has been previously recognized. were associated with Vietnamese cave rocks. We conducted quantitative PCR assays on DNA

142 extracted from rocks that were incubated in the live mesocosms using primers that targeted the particulate methane monoxygenase ( $p m o \mathrm{~A})$ gene, which is responsible for bacterial $\mathrm{CH}_{4}$

144 oxidation (see Supplementary Information for more detail). From this, we recovered $1.0 \cdot 10^{4}$ to $1.5 \cdot 10^{4}$ pmoA gene copies per gram of rock biofilm. When standardized by $16 \mathrm{~S}$ rRNA gene 146 copy number, we estimate that the relative abundance of methanotrophs in the cave biofilms ranged from 0.16 to $1.48 \%$ of the microbial community.

Despite recent global-scale efforts to survey the diversity of microbial communities from a wide range of habitats, reports of methane oxidizing bacteria from cave ecosystems are scarce.

150 For example, using cultivation-independent approaches, no sequences closely matching known methanotrophs were recovered from the Frasassi cave complex in central Italy (Macalady et al.,

152 2006). Methanotrophs were recovered from some, but not all Spanish caves (Fernandez-Cortes et al., 2015). In limestone caves of Kartchner Caverns, Arizona (USA), a single sequence was

154 recovered that was closely related to Methylocella, which is a facultative methanotroph (Ortiz et al., 2013). Similarly, only one sequence from the walls of a karstic cave in Slovenia was closely

156 related to Methylococcus, which is an obligate methanotroph (Pašič et al., 2010). In contrast, the presence and activity of methanotrophs was documented in water and mat samples collected 158 from Movile Cave using stable isotope probing (SIP). In this study, researchers tracked ${ }^{13} \mathrm{C}$ labeled $\mathrm{CH}_{4}$ into the DNA of bacteria that were closely related to known methanotrophs such as 160 Methylomonas, Methylococcus, and Methylocystis/Methylosinus (Hutchens et al., 2004). Given 
their potential role in consuming subterranean $\mathrm{CH}_{4}$, more studies are needed to characterize the

162 diversity and activity of methanotrophs in a wider range of cave ecosystems.

In the methane-depleted Castañar Cave in Spain, the importance of methanotrophy was

164 ruled out based on the assumption that bacteria would not be able to meet their metabolic demands for maintenance and growth (Fernandez-Cortes et al., 2015). However, this argument

166 overlooks two important ecophysiological features of microorganisms in natural ecosystems.

First, growing evidence suggests that many microorganisms can tolerate extreme energy

168 limitation on timescales ranging from centuries to millennia (Hoehler \& Jørgensen, 2013) owing to life-history strategies such as dormancy (Lennon \& Jones, 2011). Second, microorganisms in

170 nature are commonly challenged with "feast or famine" conditions. For example, the supply of $\mathrm{CH}_{4}$ to cave habitats varies through time depending on the source of $\mathrm{CH}_{4}$, seasonality,

172 ventilation, microclimatic conditions, and geography. Methanotrophic bacteria in caves are likely adapted to such fluctuations in $\mathrm{CH}_{4}$ concentrations, which are not captured with synoptic

174 sampling.

176 Conclusion - Although ionizing radiation can accumulate in poorly vented, deep recesses of some caves, this is neither necessary nor sufficient to explain the pattern of $\mathrm{CH}_{4}$ depletion in

178 subterranean ecosystems. Both theoretical and experimental lines of evidence suggest it is unlikely that radiolytically induced $\mathrm{CH}_{4}$ oxidation serves as a significant mechanism for rapid

180 depletion of $\mathrm{CH}_{4}$ in cave air. Rather, our results support the hypothesis that bacterial methanotrophy alone has the potential to significantly oxidize $\mathrm{CH}_{4}$ in caves, but also smaller-size

182 open subterranean spaces, such as cracks, fissures, and other pores that are connected to the atmosphere. 


\section{ACKNOWLEDGEMENTS}

186 We acknowledge support from the U.S. Department of Energy, Office of Science, Office of Basic Energy Sciences (DE-SC0006978 to A.S.); the National Science Foundation (1442246 to

188 J.T.L); the U.S. Army Research Office (W911NF-14-1-0411 to J.T.L.); the Indiana University Office for the Vice President of International Affairs; the Indiana University College of Arts and

190 Sciences; and the Indiana University Provost's Travel Award for Women in Science. We thank G. Etiope for constructive feedback on an earlier version of this manuscript and G. Crouch for

192 discussions about radiation physics. In addition, we thank B. K. Lehmkuhl for technical support, along with Minh Schimmelmann and Bui Thi Viet Ha for logistical support. Corresponding data 194 and code for this manuscript can be found at https://github.com/LennonLab/radiolyticCH4. 


\section{REFERENCES}

198 Alvarez-Gallego M, Garcia-Anton E, Fernandez-Cortes A, Cuezva S, Sanchez-Moral S. High radon levels in subterranean environments: monitoring and technical criteria to ensure human safety (case of Castañar cave, Spain) (2005). Journal of Environmental Radioactivity 145, 19-29.

202 Cigna AA (2005) Radon in caves. International Journal of Speleology 34, 1-18.

Fernandez-Cortes A, Cuezva S, Alvarez-Gallego M, Garcia-Anton E, Concepcion P, Benavente D, Jurado V, Saiz-Jimenez C, Sanchez-Moral S (2015) Subterranean atmospheres may act as daily methane sinks. Nature Communications 6, 7003.

Groffman PM, Hardy JP, Driscoll CT, Fahey TJ (2006) Snow depth, soil freezing, and fluxes of carbon dioxide, nitrous oxide and methane in a northern hardwood forest. Global Change Biology 12, 1748-1760

Hoehler TM, Jørgensen BB (2013) Microbial life under extreme energy limitation. Nature Reviews Microbiology 11, 83-94.

Hutchens E, Radajewski S, Dumont MG, McDonald IR, Murrell CJ (2004) Analysis of methanotrophic bacteria in Movile Cave by stable isotope probing. Environmental Microbiology 6, 111-120.

214 IPCC (2013) The Physical Science Basis. Contribution of Working Group I to the Fifth Assessment Report of the Intergovernmental Panel on Climate Change (eds. Stockner TF et al.) Cambridge University Press.

Lennon JT, Jones SE (2011) Microbial seed banks: ecological and evolutionary implications of dormancy. Nature Reviews Microbiology 9, 119-130. 
Macalady JL, Lyon EH, Koffman B, Albertson LK, Meyer K, Galdenzi S, Mariani S (2006) Dominant microbial populations in limestone-corroding stream biofilms, Frasassi cave system, Italy. Applied and Enviornmental Microbiology 72 5596-5609.

Mattey DP, Fisher R, Atkinson TC, Latin J-P, Durrel R, Ainsworth M, Lowry D, Fairchild IJ (2013) Methane underground air in Gibraltar karst. Earth and Planetary Science Letters 374, 71-80.

Ortiz M, Neilson JW, Nelson WM, Legatzki A, Byrne A, Yu Y, Wing RA, Soderulund CA, Pryor BM, Pierson LS, Maier RM (2013) Profiling bacterial diversity and taxonomic composition on speleothem surfaces in Kartchner Caverns, AZ. Microbial Ecology 65

Pašič L, Kovče B, Sket B, Herzog-Velikonja B (2010) Diversity of microbial communities $371-383$. colonizing the walls of a Karstic cave in Slovenia. FEMS Microbiology Ecology 71 50-60

Peryt TM, Kurakiewicz T, Peryt D, Poberezhskyy A (2012) Carbon and oxygen isotopic composition of the Middle Miocene Badenian gypsum-associated limestones of West Ukraine. Geologica Acta 10, 319 - 332.

234 Suwanwaree P, Robertson GP (2005) Methane oxidation in forest, successional, and no-till agricultural ecosystems: effects of nitrogen and soil disturbance. Soil Science Society of America Journal 69, 1722-1729

US EPA (US Environmental Protection Agency) (2015) Inventory of U.S. greenhouse gas emissions and sinks: 1990 - 2013.

von Fischer JC, Butters G, Duchateau PC, Thelwell RJ, Siller R (2009) In situ measures of methanotroph activity in upland soils: A reaction-diffusion model and field observation of water stress. Journal of Geophysical Research 114, 0148-0227/09/2008JG000731 
bioRxiv preprint doi: https://doi.org/10.1101/034801; this version posted February 17, 2016. The copyright holder for this preprint (which was not certified by peer review) is the author/funder, who has granted bioRxiv a license to display the preprint in perpetuity. It is made available under aCC-BY 4.0 International license.

242 Whalen SC, Reeburgh WS (1990) Consumption of atmospheric methane by tundra soils. Nature

346, 160-162. 
246 Fig. 1. Rates of methane $\left(\mathrm{CH}_{4}\right)$ oxidation were not significantly affected by ionizing radiation. We conducted a laboratory experiment where we tracked the concentration of $\mathrm{CH}_{4}$ in a 248 polyethylene bag containing air and ionizing radiation from a source of uranium metal powder (black line, $\mathrm{n}=1$ ) to the concentration of $\mathrm{CH}_{4}$ in control bags without an added source of

250 ionizing radiation (grey lines, $\mathrm{n}=7$ ). We attribute the slow loss of $\mathrm{CH}_{4}$ in all trials to diffusion through polyethylene bag.

Fig. 2. Field mesocosm experiments in two Vietnamese caves support the biological methane

$254\left(\mathrm{CH}_{4}\right)$ oxidation hypothesis. Control mesocosms contained no cave rocks and provided an estimate for the diffusive loss of $\mathrm{CH}_{4}$; "dead" mesocosms contained cave rocks that were treated

256 with a $10 \%$ bleach solution; "live" mesocosms contained cave rocks and a volume of water (150 $\mathrm{mL}$ ) equivalent to the volume of bleach used in the "dead" treatment. The dashed horizontal lines

258 correspond to the $\mathrm{CH}_{4}$ concentrations in the Hoa Cương and Minh Châu caves on Cát Bà island, northern Vietnam. 
bioRxiv preprint doi: $\mathrm{https}$ //doi.org/10.1101/034801; this version posted February 17, 2016. The copyright holder for this preprint (which was not certified by peer review) is the author/funder, who has granted bioRxiv a license to display the preprint in perpetuity. It is made available under aCC-BY 4.0 International license.

Fig. 1.

262

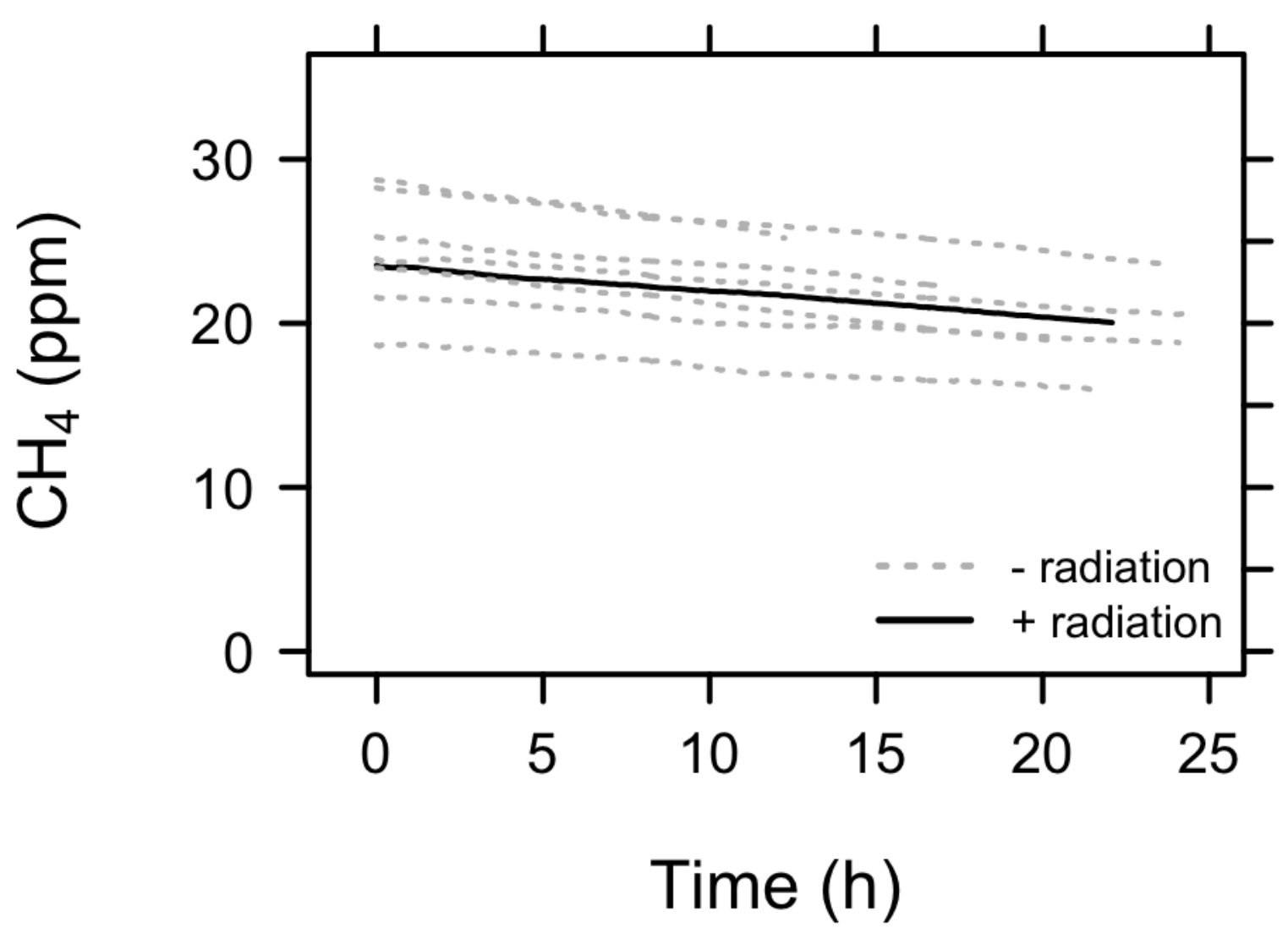


Fig. 2.

Hoa Cương

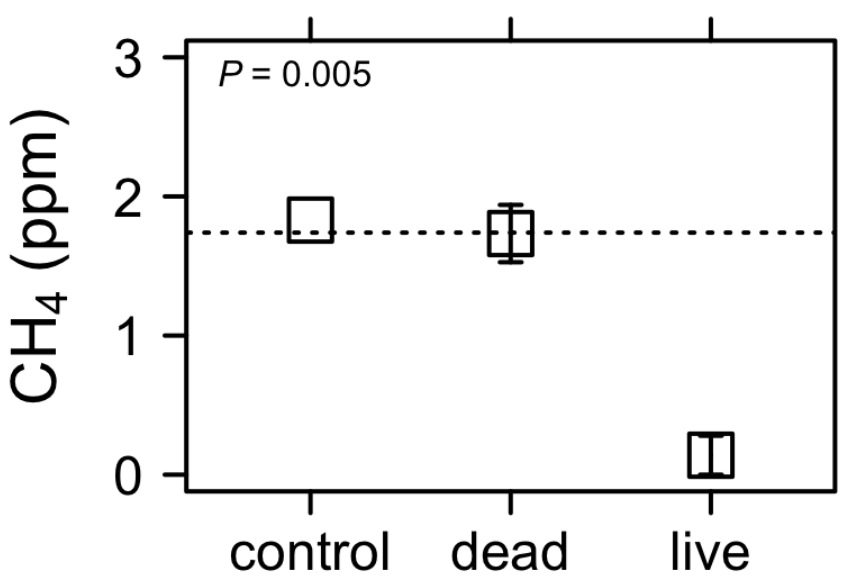

Minh Châu

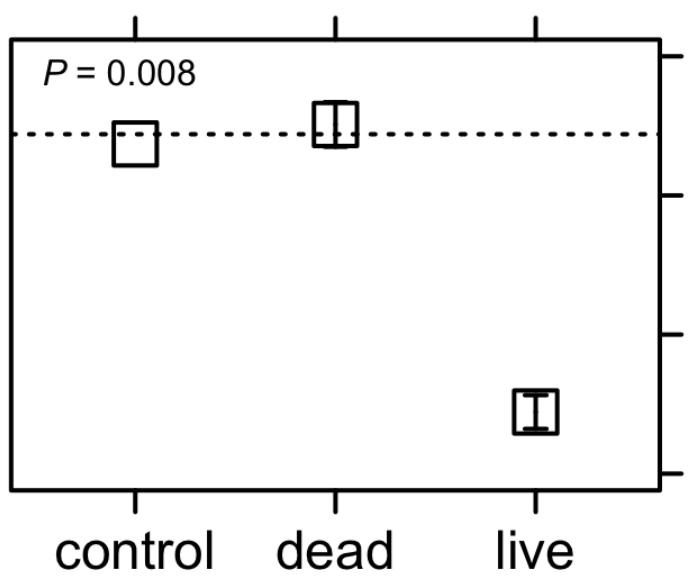

